\title{
STOP 5: Veselava end moraine, north-western Vidzeme Upland
}

\author{
Vitālijs Zelčs, Māris Krievāns and Ivars Strautnieks
}

University of Latvia

The retreat of the Late Weichselian Fennoscandian ice sheet over the north-western part of the Vidzeme Upland is marked by three major ice-marginal zones (in order of decreasing age and hypsometric position: Kaldabruņa, Gulbene and Linkuva) (Meirons et al. 1976; Zelčs et al. 2011). Traditionally, these ice-marginal zones have tentatively been correlated with the South Lithuanian, Middle Lithuanian and North Lithuanian ice-marginal zones in Lithuania, respectively (Āboltiņš et al. 1972; Āboltiņš et al. 1975; Meirons et al. 1976; Zelčs and Markots 2004), but new OSL dates from the Middle Gauja Lowland (Nartišs and Zelčs 2011) shed doubt on the previous interregional correlation (ibid.) of the Linkuva ice-marginal formations with the Haanja zone in Estonia.

The Veselava end moraine is an almost $8 \mathrm{~km}$ long and 750-1200 m wide ridge in a chain of Linkuva ice-marginal features which extend discontinuously over the outer ice contact slope of the Vidzeme Upland (Fig. 5.1). On the highest part between the Silenieki and Lỉbieši gravel pits (see Fig. 5.2 for location) its maximum elevation varies from 160 to $170.6 \mathrm{~m}$. The topmost part of the ridge has a slightly uneven recent surface topography complicated by superimposed small hillocks and elongated ridges, pitted in places. The end moraine rises above the upglacierlocated till plain by up to $30 \mathrm{~m}$, about $60 \mathrm{~m}$ above the Raunis palaeolake plain and $10-20 \mathrm{~m}$ above the bottom of the ice-marginal drainage valley (Fig. 5.2). The end moraine has an asymmetrical cross-profile, with a shorter and steeper downglacier slope.
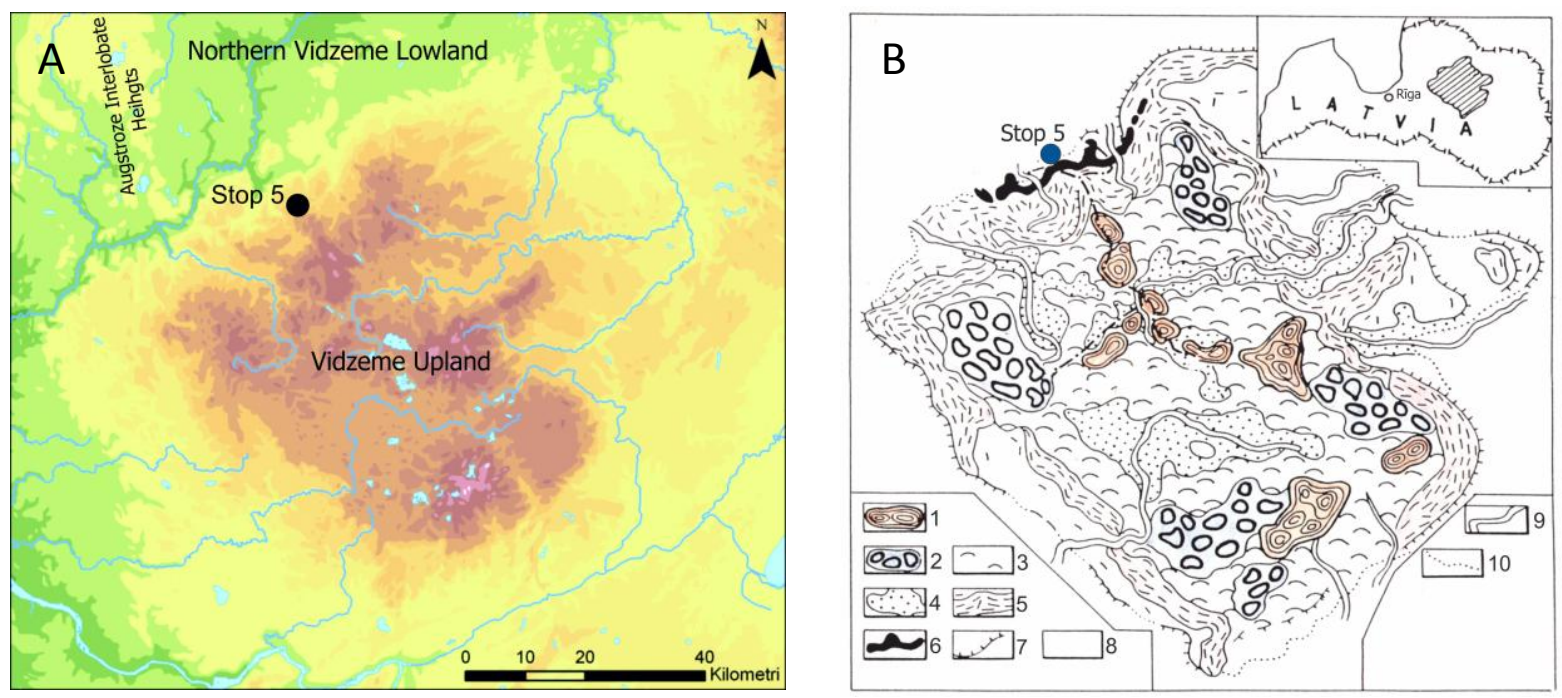

Fig. 5.1. Location of the Veselava end moraine and the stop site. A. Digital elevation model of the Vidzeme Upland and surrounding terrain. B. Geomorphological sketch of the Vidzeme Upland (modified after Āboltinš 1995). Legend: 1 - composite interlobate hilly massifs; 2 - areas of plateau-like hills; 3 - various types of hummocks (with prevalence of morainic hummocks); 4 - largest glacial depressions; 5 - ice-marginal formations of the outer zone; 6 - end moraines and ramparts of ice-tongue lateral coalescence in the outer zone; 7 - marginal slopes; 8 - rolling plains in adjoining glacial lowlands; 9 - largest river valleys; 10 - boundary of the Vidzeme Upland.

The hypsometric position of the bedrock surface ranges from $50-80 \mathrm{~m}$ to $100-110 \mathrm{~m}$ a.s.l. The end moraine is located next to the area of the lithological boundary between Devonian terrigenous and carbonate sedimentary rocks. This boundary is morphologically expressed as a dolomite escarpment up to $40 \mathrm{~m}$ high covered by less than $12 \mathrm{~m}$ thickness of Quaternary 
sediments. Weakly cemented sandstone or soft silt and clay is found underlying small, low bedrock depressions, whose strike coincides with the ice flow direction or buried valleys which tend follow the edge of the dolomite escarpment. These small bedrock depressions have a tongue-like shape and are quite well reflected in the modern topography (Fig. 5.2, note River Raunis depression). Presumably, due to the faster ice flow in the centre of the bedrock depression in comparison to ice flow alongside the lateral slopes, the Veselava end moraine is slightly curved downglacier. Dolomite forms the most elevated compartments of the subQuaternary surface. In addition, the dolomite plates gently dip against the ice movement direction with a gradient of about $9 \mathrm{~m}$ per $1000 \mathrm{~m}$. Evidently, this has stimulated glacier rafting and assimilation of local dolomitic bedrock material. The Veselava end moraine rests on dolomite, at a minimum distance of only $2-3 \mathrm{~km}$ downglacier from the escarpment.

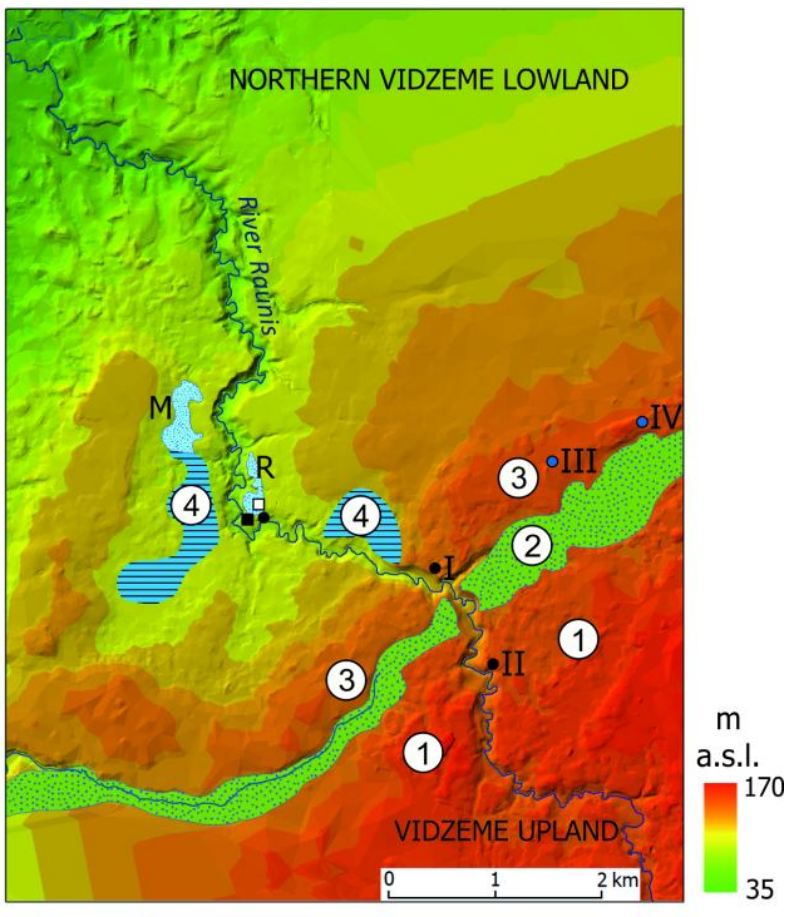

Fig. 5.2. Digital elevation model of the Veselava end moraine and adjoining area. Legend:

1 - Gulbene ice-marginal zone; 2 - ice-marginal drainage channel; 3 - Veselava end moraine of Linkuva phase ice-marginal zone; 4 - occurrence of glaciolacustrine deposition at levels of 125-140 m a.s.l. Late-glacial and Early Holocene palaeolakes with the highest level $110 \mathrm{~m}$ a.s.l: $\mathrm{R}$ - Raunis; $\mathrm{M}$ Mīlǐši. Figures I and II denote location of sections studied by Āboltinšs (1972, 1975), III and IV location of Silenieki and Lībieši gravel pits, respectively.

The thickness of Pleistocene deposits in the Veselava end moraine is $40 \mathrm{~m}$ on average. In general they thin out in the proximal direction. The buried bedrock valley, which coincides with an ice-marginal drainage channel (Fig. 5.2), is filled with an almost 100-m-thick sequence mainly composed of till (tentatively assigned by Meirons and Straume (1979) to Middle and Upper Pleistocene glacials), with interlayered thin glacioaquatic sediments. Between the two upper till units warmer period sediments were found in a coring section placed distally from the end moraine. Similar silty sand sediments with silt and clay intercalations containing disseminated organics and macroscopic plant remains were encountered by Āboltiňš (pers. comm.) in the lower part of both sections (see Fig. 5.2: I and II for location), studied at the beginning of the 1970s (Āboltiņš 1972, 1975).

Āboltinss $(1972,1975,1989)$ emphasized the complicated internal structure of the exposed deposits, noting the abundance of glaciotectonic deformation in bedded and laminated gravel, sand, silt, clay and basal till. He (ibid.) divided the Veselava end moraine cross-section into two different parts: the lower portion, with intensive glaciotectonic folding, and the topmost part, where these folded strata are overlain by up to four imbricate thrust scales of till with assimilation contacts at the base of some till sheets. In addition, the till overthrusted scales are capped by thin $(2-3 \mathrm{~m})$ sandy gravel with sandwiched silt and silty sand interlayers. Glaciokarst phenomena are also common in the covering strata, giving rise to some topographic undulations.

The Silenieki and Lìbieši gravel pits are located on the highest part of the end moraine ridge and have a more lateral position in comparison to the sections studied by Āboltinšs (Fig. 5.2). 


\section{Silenieki gravel pit section}

The section is located in the topmost part of the end moraine $\left(25^{\circ} 29^{\prime} 35^{\prime \prime} \mathrm{E}, 57^{\circ} 17^{\prime} 58^{\prime \prime} \mathrm{N}\right)$. The surface of the end moraine abounds in erratic boulders. The exposed sequence is up to 4 $\mathrm{m}$ thick. In its upper part this section, transverse to the moraine ridge crest, consists of pebbles with cobbles interlayered by massive diamicton (Fig. 5.3). The diamicton macrofabric is relatively strong, but dispersed. The macrofabric maximum strikes at an acute angle to the moraine ridge crest. Strong fabric is common in the direction of shear (Bennett and Glasser 2009). Both shear zones in the section can be interpreted as proglacial thrusting. The material is poorly sorted, coarsening upward, and contains a lot of local dolomite clasts. The dolomite clasts are angular, in places striated and faceted. The coarse clastic part of the section is underlain by silt of varying thickness. The lower contact of the silt apparently originates from erosion of the underlying fine-grained sand interlayered with silt. On the right hand side of the section both lithological units are folded concordantly with one another, probably because of mass flow.

The OSL age of burial of the sand deposited in the lower part of the Silenieki section is $59 \pm 10 \mathrm{ka}$. An OSL date of $33.6 \pm 6.4 \mathrm{ka}$ of has been obtained in the northern part of the Burtnieks drumlin field, in the vicinity of Rüjiena town. This seems to indicate sand deposition during the Middle Weichselian interstadial.

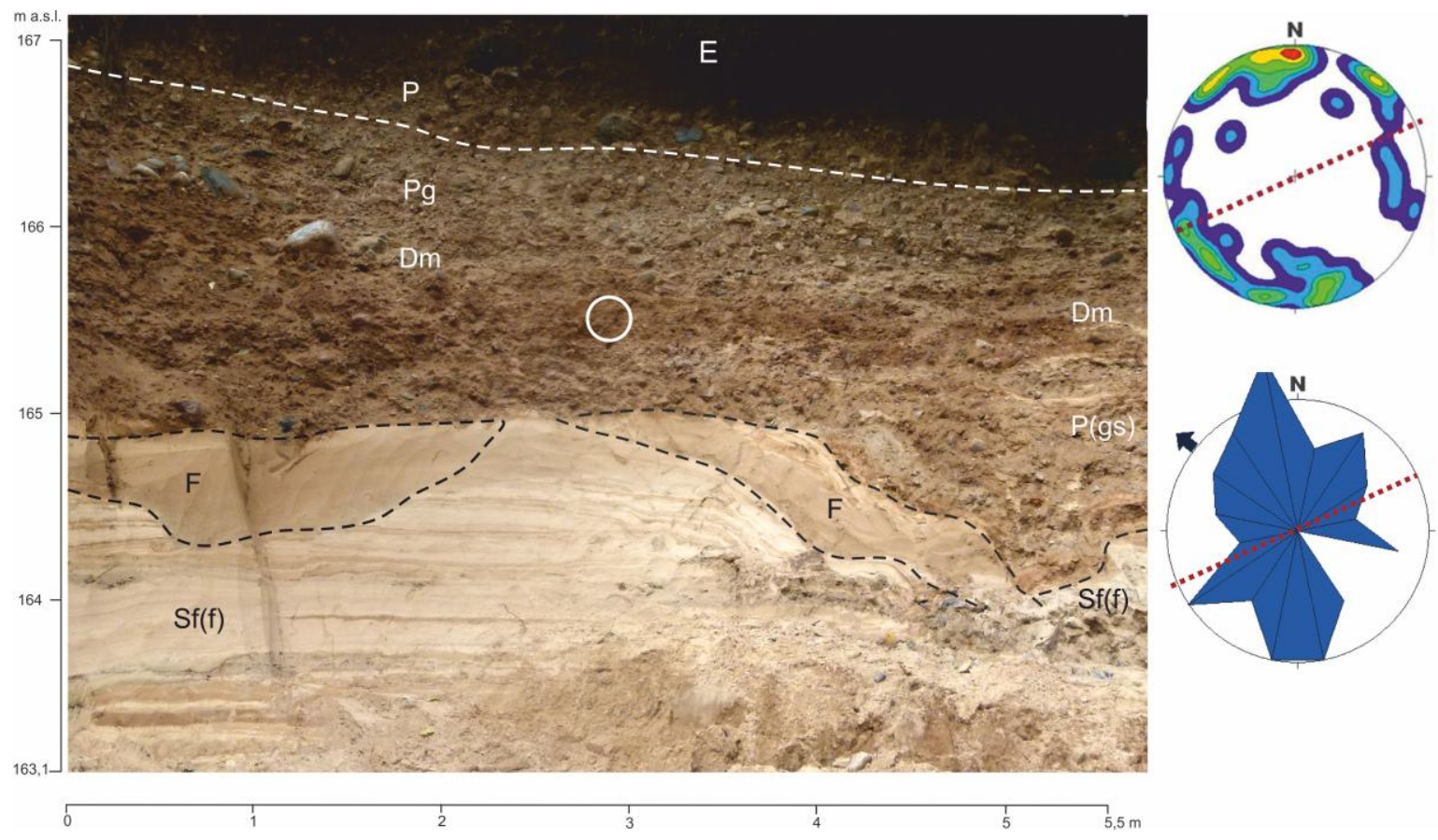

Fig. 5.3. Internal structure of the topmost part of the Veselava end moraine in the Silenieki gravel pit and clast fabric countour and rose diagrams in the lower diamicton interlayer.

Legend: F - silt, Dm - diamicton massive, P - pebbles with occasional cobbles, Pg - pebbles and gravel; P(gs) pebbles and gravel mixture with sand matrix, $\mathrm{Sf}(\mathrm{f})$ - fine grained sand interlayered by silt, $\mathrm{F}$ - fines. Large circle denotes macrofabric measurement site, red dotted line shows strike of the end moraine ridge crest.

Three-dimensional diagram of macrofabric orientation is on the lower hemisphere and in equal area projection. Based on 50 macrofabric measurements. Contoured at $0-1-2 \ldots 7$ percent areas.

\section{Lībieši gravel pit section}

This section is located about $1.5 \mathrm{~km}$ ENE of the Silenieki site $\left(25^{\circ} 30^{\prime} 53,938^{\prime \prime} \mathrm{E}\right.$ $\left.57^{\circ} 18^{\prime} 12,365^{\prime \prime N}\right)$. It displays supra-glacial meltout till, probably altered by gravity flow (Fig. 5.4). The supraglacial till consist of rare pebbles in an abundant matrix rich in sandy silt and clay. Till macrofabric is variable and poorly developed (Fig. 5.4). Nevertheless, some 
packages probably show different flow directions. In places bent lenses or chunks of silty sand can be encountered. The supraglacial till is underlain by pebbles with occasional cobbles and gravel admixture. This part of the section is similar to the composition of the uppermost part of the Silenieki section.

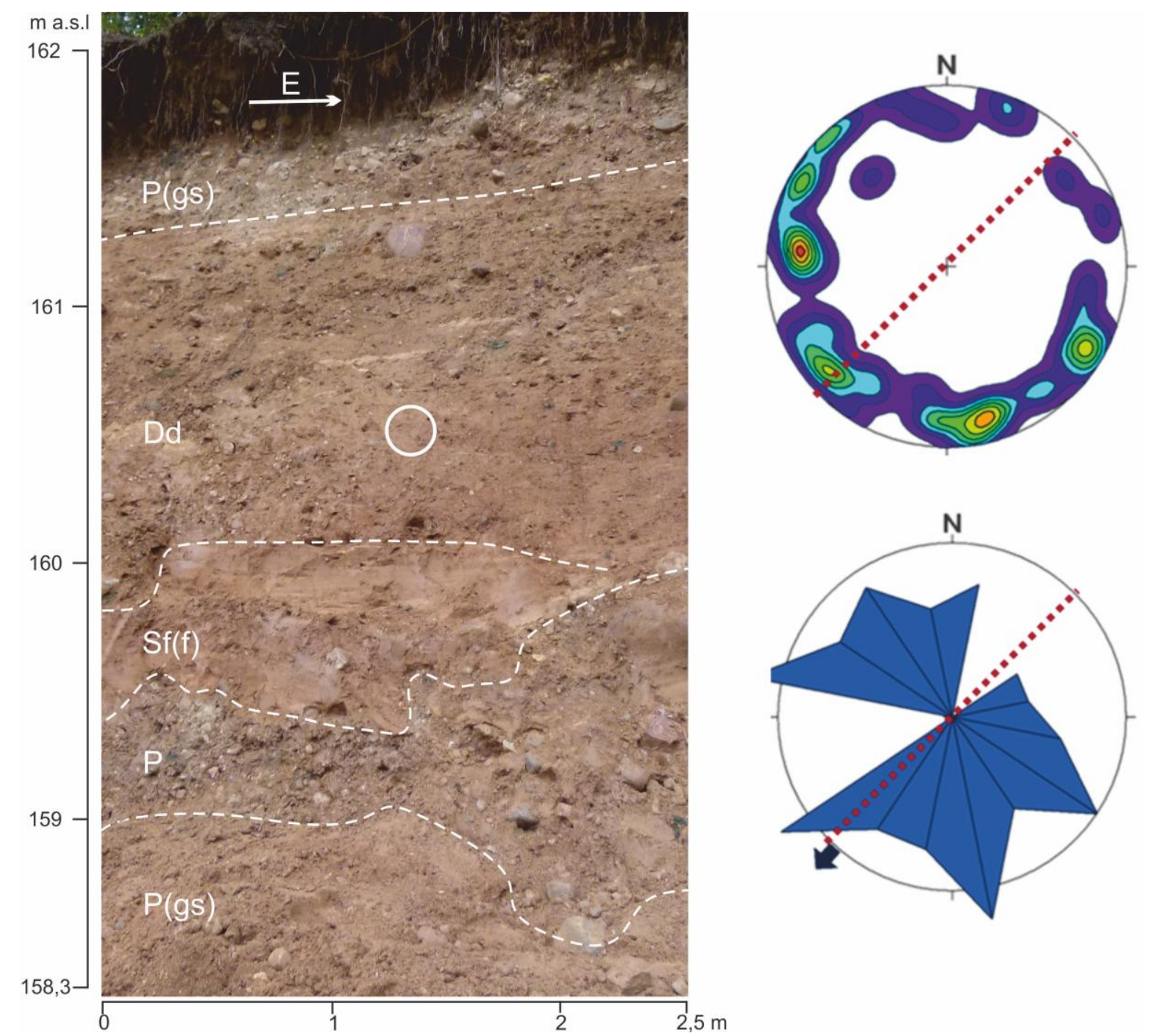

Fig. 5.4. Internal structure of the uppermost part of the Veselava end moraine in the Lỉbieši gravel pit and clast fabric diagram of the stratified diamicton.

Legend: Dd - diamicton with minor deformation structures, $\mathrm{P}$ - pebbles with occasional cobbles, $\mathrm{P}(\mathrm{gs})$ - pebbles with gravel admixture, $\mathrm{Sf}(\mathrm{f})$ - fine grained sand interlayered with silt. Large circle denotes macrofabric measurement site, red dotted line shows strike of ridge crest.

Three-dimensional diagram of macrofabric orientation is on the lower hemisphere and in equal area projection. Based on 50 macrofabric measurements. Contoured at $1-2 \ldots 8$ percent areas.

To sum up, the Veselava end moraine contains both mass-flow and waterlain sediments, and evidence of proglacial thrusting during small oscillations of the glacier terminus. Formation of ice-marginal moraines by a combination of proglacial thrusting and gravity processes (high sediment mobility) during the melting out of buried ice blocks is also suggested by Knight (2006). The morphometric parameters of the Veslava moraine most probably indicate that the glacier transported a large amount of drift with a high content of local bedrock fragments, and that glacier flow was relatively fast. In places, after glacier retreat, the end moraine ridge has been fragmented by subsequent fluvial erosion.

According a model of end moraine sedimentation based on data from Pleistocene ice 
sheet margins proposed by Krzyszkowski and Zieliński (2002), it can be classified as a B type end moraine, which represents "the most typical sequence in the end moraine zones" (Krzyszkowski and Zieliński ibid, p. 73). It is also possible that in some stretches of the Veselava end moraine where ice-marginal drainage has been hindered or promoted by proglacial topography, other types of end moraines may have developed.

\section{References}

Āboltinšs, O. 1972. Maršrut: Cesis - Veselava - Taurene - oz. Alauksts - oz. Zobols - Skujene - Nitaure - Ligatne Sigulda - Riga [Field trip Cesis - Veselava - Lake Alaksts Lake Zobols -Skuyene - Nitaure - Ligatne Cesis]. In: Danilāns, I., Āboltiňš, O. (eds.), Putevoditel polyevogo simpoziuma IV Vsesoyuznogo soveschanija po izucheniju krajevykh obrazovanij materikovogo oledenenija [Guide of the Field symposium of the IV All-Union meeting on studies of marginal formations of continental glaciation]. LGU im. P. Stučki, Rīga, pp. $47-59$ (in Russian).

Āboltinš, O. 1975. Glaciodynamic peculiarities of the formation of Latvian elevations. In: Danilans, I. (ed.), Problems of Quaternary geology, 8. Zinātne, Rīga, pp. 5-23 (in Russian, with English summary).

Āboltinš, O. P. 1989. Glyatsiostruktura i lednikovy morfogenez [Glaciotectonic structure and glacial morphogenesis]. Rìga: Zinātne, 284 pp. (In Russian).

Āboltiņš, O. 1995. Vidzeme Highland. In: Schirmer (ed.), INQUA 1995. Quaternary field trips in Central Europe. C-3 Baltic Traverse. Verlag Dr. Friedrich Pfeil, Munchen, Germany, pp. 159-162.

Āboltinšs, O., Straume, J., Juškevičs, V. 1975. Relief peculiarities and main stages of morphogenesis of Central Vidzeme Upland. In Danilāns, I. (ed.), Problems of Quaternary Geology, 8, Zinātne, Rīga, pp. 31-47 (in Russian, with English summary).

Āboltiņš, O.P., Veinbergs, I.G., Stelle, V.J., Eberhards, G.J. 1972. Osnovniye kompleksy marginal'nykh obrazovaniy i otstupaniye lednika na territorii Latviiskoy SSR [Main complexes of marginal formations and glacier retreat in the territory of Latvian SSR]. In: Goretskij, G. I., Pogulajev, D. I., Shick, S. M. (eds.), Krayevye obrazovaniya materikovykh oledeneniy [Marginal formations of continental glaciations]. Nauka, Moskva, pp. 30-37 (in Russian).

Bennett, M.M., Glasser, N.G. 2009. Glacial geology: ice sheets and landforms, 2nd edition. Wiley-Blackwell, 385 pp.

Krzyszkowski, D., Zieliński, T. 2002. The Pleistocene end moraine fans: controls on their sedimentation and location. Sedimentary geology, 2002, 73-92.

Knight, J. 2006. Geomorphic evidence for active and inactive phases of Late Devensian ice in north-central Ireland. Geomorphology, 75, 4-19.

Meirons, Z., Straume, J. 1979. Kaynozoyskaya grupa [Cenozoic group]. In: Misans, J., Brangulis, A., Danilans, I., Kuršs, V. (eds), Geologicheskoe stroyenie i poleznye iskopayemye Latvii [Geological structure and mineral resources of Latvia]. Zinātne, Rīga, pp. 176-268. (In Russian).

Meirons, Z., Straume, J., Juškevičs, V. 1976. Main varieties of the marginal formations and deglaciation of the Last glaciation in the territory of the Latvian SSR. In Danilāns, I. (ed.), Problems of Quaternary Geology, 9. Rīga, Zinātne, pp. 50-73 (in Russian, with English summary).

Nartišs, M., Zelčs, V. 2011. A succession of Lateglacial ice-dammed lakes in north Vidzeme, Latvia. In: Johansson, P., Lunkka, J.-P., Sarala, P. (eds.), Late Pleistocene Glacigenic Deposits from the Central Part of the Scandinavian Ice Sheet to Younger Dryas End Moraine Zone. Excursion Guide and Abstracts of the INQUA Peribaltic Working Group Meeting and Excursion in Finland, 12-17 June 2011. Geological Survey of Finland, Rovaniemi, p. 122.

Zelčs, V., Markots, A. 2004. Deglaciation history of Latvia. In: Ehlers, J., Gibbard, P. L. (eds.), Quaternary Glaciations - Extent and Chronology. Part I: Europe. Developments in Quaternary Science, 2. Elsevier, Amsterdam, pp. 225-243.

Zelčs, V., Markots, A., Nartišs, M., Saks, T. 2011. Chapter 18: Pleistocene Glaciations in Latvia. In: Ehlers, J., Gibbard, P.L., Hughes, P.D. (eds.), Quaternary glaciations - extent and chronology. A closer look. Developments in Quaternary Science, 15. Elsevier, pp. 221-229. 

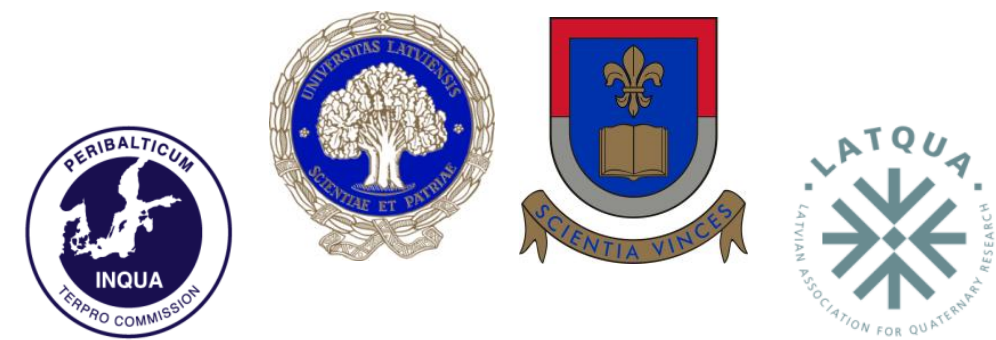

INQUA TERPRO COMMISSION PERIBALTIC WORKING GROUP

UNIVERSITY OF LATVIA

UNIVERSITY OF DAUGAVPILS

LATVIAN ASSOCIATION FOR QUATERNARY RESEARCH

\section{LATE QUATERNARY \\ TERRESTRIAL PROCESSES, SEDIMENTS AND HISTORY: FROM GLACIAL TO POSTGLACIAL ENVIRONMENTS}

EASTERN AND CENTRAL LATVIA

AUGUST 17-22, 2014 


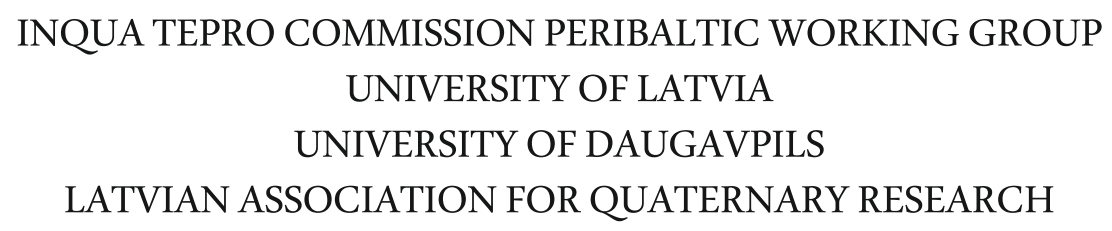

\title{
LATE QUATERNARY \\ TERRESTRIAL PROCESSES, SEDIMENTS AND HISTORY: FROM GLACIAL TO POSTGLACIAL ENVIRONMENTS
}

\author{
EASTERN AND CENTRAL LATVIA
}

AUGUST 16-22, 2014 
Organized by:

University of Latvia

Daugavpils University

Latvian Association for Quaternary Research

INQUA Peribaltic Working Group (INQUA TERPRO Commission)

Organizing committee:

Māris Nartišs (Chair, University of Latvia)

Māris Krievāns (Secretary, University of Latvia)

Aivars Markots (University of Latvia)

Juris Soms (Daugavpils University)

Evija Tērauda (University of Latvia)

Vitālijs Zelčs (University of Latvia)

Contributors:

Ivars Celiņš, Edgars Greiškalns, Ieva Grudzinska, Edyta Kalińska-Nartiša, Laimdota Kalniņa, Jānis Karušs, Māris Krievāns, Kristaps Lamsters, Aivars Markots, Māris Nartišs, Agnis Rečs, Normunds Stivriņš, Juris Soms, Ivars Strautnieks, Santa Strode, Sandra Zeimule, Vitālijs Zelčs

Editors: Vitālijs Zelčs and Māris Nartišs

The English texts of the field guide were revised by Valdis Bērziņš

Recommended reference for this publication:

Zelčs, V. and Nartišs, M. (eds.) 2014. Late Quaternary terrestrial processes, sediments and history: from glacial to postglacial environments. Excursion guide and abstracts of the INQUA Peribaltic Working Group Meeting and field excursion in Eastern and Central Latvia, August 17-22, 2014. University of Latvia, Rīga, 2014, 150 pages.

Sponsored by:

University of Latvia

Layout: Vitālijs Zelčs, Māris Nartišs and Māris Krievāns

ISBN 078-9934-517-60-0

(C) University of Latvia, 2014

This volume is available from:

Faculty of Geography and Earth Sciences

University of Latvia

Rainis Blvd. 19

Rìga, LV1586

Latvia 